Guðrún Jónsdóttir er født i 1958 og er cand.polit. med hovedfag i sosialpedagogikk. Hun har bred erfaring fra

skoleverket som lærer, rådgiver og pedagogisk veileder. Siden 1992 har hun vært ansatt som høyskolelektor $\mathrm{i}$

pedagogikk ved Høgskulen i Sogn og Fjordane og er nå stipendiat ved samme høyskole.

\title{
Kroppen i naturfagrommet
}

\begin{abstract}
This article focuses on 16-17 year old girls' interest in the body as a topic in science class and their approach to school science in lower secondary and in upper secondary education. How can we put their interest into perspective? The body has become a project which should be worked at and accomplished as part of an individual's self-identity. By viewing the body as a project, individuals may become conscious of and actively concerned about the management, maintenance and appearance of their body. I argue that the girls` enthusiasm for the body as a topic in science class is influenced by their perception of health risks and need to be in control of their own body.
\end{abstract}

\section{INNLEDNING}

Denne artikkelen handler om ni 16 - 17 år gamle jenter og deres interesse for temaet kroppen i naturfag ${ }^{1}$. Jentene har gått i samme klasse på en ungdomsskole i en liten bygdeby ${ }^{2}$. Jeg har fulgt dem fra tiende klasse på ungdomstrinnet til første året på videregående skole.

I møtet med disse jentene får jeg et bilde av aktive jenter, som alle lever et velordnet familieliv med mor, far og søsken. Lone, en av de ni jentene, svarte slik da jeg ba henne om å fortelle litt om seg selv: Jeg bor med mamma, pappa og lille broren min som er 13 år. Og så har vi en katt. Jeg danser ballett og jeg går på drama. Jeg trener også litt på treningsstudio og aerobic og slikt. Om vinteren liker jeg å stå på telemark. Når det gjelder interesser og familieforhold, er Lone på mange måter representativ for jentene i utvalget.

Jentene er skoleflinke, spesielt i tiende klasse fikk de gode karakterer. På ungdomsskolen var de da også svært opptatt av skolearbeid. Både jentenes klasseforstander og enkelte av jentene gir uttrykk for at det til tider har blitt litt for mye av det gode. Naturfag var et fag jentene likte godt i tiende klasse. Etter at de begynte på videregående skole, oppleves faget som et ork. Karakterene synker, og faget oppleves som vanskelig. Men når det gjelder hvilke tema jentene liker best $\mathrm{i}$ naturfag, finner jeg ingen endringer. Fortsatt er det kropp som er på topp. Jeg stiller spørsmålet: Hvordan kan vi forstå jentenes interesse for temaet kroppen i naturfag?

\footnotetext{
${ }^{1}$ I henhold til Læreplanen av 1997(L97) heter det obligatoriske naturfag i norsk grunnskole natur- og miljøfag. Jentene i mitt utvalg begynte på skolen høsten 1997, og har med andre ord fått opplæring etter L97. I videregående skole heter det obligatoriske 5-timers kurset naturfag. Studieretningsfaget som elevene kan velge til videre fordyping er spesialiserte kurs i fysikk, kjemi og biologi.

${ }^{2}$ Et tettsted på landsbygda med ca 7000 innbyggere, heretter kalt Bygdeby
} 


\section{Hva sier tidligere forskning?}

Jentenes interesse for temaet er i tråd med flere undersøkelser som omhandler elevers holdninger til naturfag. Resultatene fra disse undersøkelsene antyder at biologi er et fag jenter liker bedre enn det gutter gjør (for en oversikt se Nergård, 2003; Osborne og Collins, 2003). Forskningen viser også at det fremdeles er forskjeller når det gjelder hvilke emner jenter og gutter liker best (Roger 2000). Spesielt ser det ut til at jenter liker temaer som kan relateres til kropp og helse bedre enn gutter (Schreiner, 2003; Sjøberg, 2001; Teppo, 2004). De fleste av de refererte undersøkelsene om elevenes holdninger er store kvantitative undersøkelser (for en oversikt se Osborne 2003). Det er vanlig i mange av disse undersøkelsene å studere holdninger ved bruk av Likert-skala (Osborne, 2003). Gjennom surveys kartlegges elevenes preferanser i forhold til å arbeide med ulike emner i naturfag (Schreiner, 2003; Simon, 2000; Sjøberg, 2002). Fordelene ved bruk av surveys med lukkede spørsmål er blant annet at de er lette å svare på, og de gjør det mulig å sammenlikne svar fra ulike respondenter. Osborne og Collins (2003) påpeker at disse undersøkelsene har møtt kritikk, da de resultatene som har kommet frem i dem bare identifiserer elevenes holdninger. De er til liten hjelp når vi skal prøve å forstå bakgrunnen for disse holdningene. Jentenes interesse for kroppen er også i tråd med nyere undersøkelser som viser at vi i dagens samfunn har fått "nye jenter" 3, som ikke har det minste problem med å hevde og markere seg selv (Nielsen, 2004). Fra politisk hold blir det ofte fokusert på dalende rekruttering til realfaglige studier. En rapport utarbeidet på oppdrag av Nordisk Ministerråd, av Norsk institutt for studier av forskning og utdanning/Senter for innovasjonsforskning (2002), viser at rekrutteringen varierer i de nordiske landene, men det er ikke et grunnlag for å hevde at det er en generell nedgang eller svikt i rekrutteringen til realfagene. Rapporten viser imidlertid at markante kjønnsforskjeller er et gjennomgående trekk for alle landene.

I de senere år har det kommet flere viktige forskningsbidrag som har tematisert kroppen på forskjellig vis (Brumberg, 1997; Børtnes, Kraft, \& Mikkaelsson, 2004; Holsen , 2002; Shilling, 1994, 2003). Flere av disse bidragene fremstiller vårt forhold til kroppen som fremmedgjort (Rudberg, 2000). Andre fokuserer på at det foregår en kulturell kamp om kroppen på en rekke samfunnsarenaer. Denne kampen om kroppen kan sees som en del av større sosiale endringsprosesser i senmoderniteten. En av disse endringene, som påvirker vårt forhold til kroppen er individualismen. I den individualistiske etos blir ideen om kroppen som "min" grunnleggende, påpeker Børtnes et al. (2004).

Fra flere hold blir det påpekt at de karakteristikkene som gis av jenter og gutter og deres forhold til naturfag, ofte blir stereotyper som ikke fanger opp mangfoldet og variasjonene som finnes innenfor hver av kjønnsgruppene (Brickhouse, 2000; Nergård, 2003). Målet med min undersøkelse er ikke å generalisere om alle jenter og deres møte med naturfag. I undersøkelsen har jeg anledning til å gå tett på jentene og sette deres interesse for emnet kroppen min inn i en større meningssammenheng. Ved å veksle mellom oversiktsanalyse og næranalyse mener jeg å kunne få frem et rikere bilde av jentenes interesse for kroppen. I mine analyser har jeg blant annet mulighet til å undersøke jentenes begrunnelser for å like dette temaet.

\section{Forståelsen av jentenes interesse for temaet i mitt materiale}

I mitt datamateriale er det tre temaer knyttet til kropp i naturfagsundervisningen som peker seg ut som spesielt viktig for jentene. Det er seksualitet, kosthold og trening. Disse temaene knytter jentene til problemstillinger som har med helse og sunnhet å gjøre. Det er også tydelig hvordan jentene markerer at det er de selv som har ansvar for disse områdene. Jentene signaliserer samtidig at de opplever at de står overfor flere valgmuligheter. Dette vil jeg komme nærmere tilbake til når jeg tar et dypdykk i empirien.

\footnotetext{
${ }^{3}$ Nielsen påpeker at "These observation call immediately, of course, for differentiation with regard to social class and ethnicity (Nielsen 2004:10). De nye jentene er først og fremst hvite middelklassejenter, i særdeles med bosted Skandinavia.
} 
Med utgangspunkt i datamaterialet er min påstand at jentenes interesse for emnet "kroppen min" kan forstås med utgangspunkt i deres opplevelse av helserisiko og behov for å kontrollere egen kropp. Dette vil jeg knytte opp mot en forståelse av kroppen som en del av identitetsarbeidet i det refleksive moderne. Av materialet fremgår det også at jentenes interesse for kroppen går igjen når de uttaler seg om prioriteringer i naturvitenskapelig forskning, og hva de selv mener bør prioriteres. Kroppen er også et eksempel de bruker når de reflekterer over hvordan naturfaglig kunnskap har utviklet seg. Jeg setter dette i sammenheng med jentenes uttalelser om hva de stoler på, og hvordan de vurderer informasjon og kunnskap om naturfaglige fenomener. Dette kan gi oss et innblikk i jentenes vitenskapsideal. Min påstand er at deres syn på vitenskapen kan være et omdreiningspunkt for å forstå jentenes interesse for kroppen.

\section{FREMGANGSMÅTE VED FELTARBEID OG ANALYSER}

\section{Utvalg}

Adgang til feltet er ikke noe en først skaffer seg for så å samle inn data. Det å skaffe seg adgang til ulike forskningsarenaer kan i mange tilfeller gi data. Denne prosessen kan også gi viktige antagelser om hva som kan være data (Wadel, 1991). De første notatene i min feltdagbok handler om refleksjoner rundt hvor, på hvilke skoler, jeg kan forsøke å få innpass for undersøkelsen. Da jeg ønsket variasjon $\mathrm{i}$ jentegruppen valgte jeg å kontakte en ungdomsskole ${ }^{4}$ som tar i mot elever fra to forskjellige barneskoler i kommunen, en sentrumsskole og en fådelt skole i utkanten av kommunen. Jeg ønsket å følge jentene også det første året på videregående skole, og da jeg visste at et overveiende flertall av elevene fra Bygdeby ungdomsskole søker seg inn på den samme videregående skolen i Bygdeby var det også et moment som talte for å velge denne ungdomsskolen.

Ungdomsskolen har to parallelle klasser på hvert årstrinn. Da min undersøkelse startet ønsket skolens ledelse, av ulike interne årsaker, at jeg bare skulle gå inn i en av klassene. Både naturfaglæreren, eleven og foreldrene ga sitt samtykke til undersøkelse. Naturfaglæreren var svært imøtekommende og hjalp til med å arrangere det første møtet med de totalt ni jentene i klassen. På dette møtet informerte jeg om prosjektet og fridde til dem om å delta. Samtlige av de ni jentene var imøtekommende og begeistret over å bli spurt om å delta i undersøkelsen: Wow, ropte Lone, bare oss, skal du skrive en hel bok bare om oss?

\section{Feltarbeid i tiende klasse}

Feltarbeidet startet med observasjon av jentene i naturfagtimene. Intensjonen var å få kjennskap til konkrete forhold i klasserommet (verbale og ikke-verbale handlinger). Observasjonene ble brukt for å skaffe oversikt over aktiviteter og kjennetegn på situasjoner som jentene inngår i. Hendelser og fortolkninger ble notert fortløpende. Dette observasjonsmaterialet dannet grunnlag for intervjuguiden. Jentene ble først intervjuet enkeltvis ved slutten av det tiende skoleåret. Jentenes opplevelse og erfaringer med naturfag var hovedtema. Intensjonen var at jentene skulle beskrive sitt møte med naturfag og vurdere det. De ble bedt om å beskrive seg selv som jenter og som elever. Andre tema i intervjuene var jentenes forhold til og erfaring med forskning og vitenskap generelt og naturvitenskap spesielt. Spørsmålene ble konkretisert med eksempler og temaer som jeg hadde fanget opp under observasjonene i klasserommet. Intervjuene ble tatt opp på bånd og transkribert. Kommentarer og assosiasjoner ble notert parallelt med utskrivingen. Slik ble jeg kjent med materialet, og prosessen gav meg tilbakemeldinger som intervjuer.

\section{Feltarbeid på videregående skole}

Åtte av jentene går nå på videregående skole i Bygdeby, fordelt på fire klasser. Fem av jentene går på allmennfaglig studieretning, en på medielinje og to på idrettsfag. En av jentene har flyttet til en større by, der hun går på allmennfaglig studieretning.

${ }^{4}$ heretter kalt Bygdeby ungdomsskole 
Tre uker ut i høstsemesteret startet observasjonene i de klassene jentene nå gikk i på videregående skole. Klassene viste seg å være svært forskjellige, og for å drøfte dette med jentene gjennomførte jeg en to timers fokusgruppeintervju (Madriz, 2000). Her snakket jentene mye om hvordan det var å begynne på videregående. De løftet frem problemstillinger som det er vanskelig for en utforstående (forskeren) å identifisere. I tillegg til notater fra samtalen fylte jentene ut et oppsummeringsark. Jentene ble også introdusert og instruert i å skrive loggbøker. Gjennom loggbøkene skulle jeg få frem jentenes forståelse av egne opplevelser, erfaringer og roller. Logg var valgt ut fra en antagelse om at dagbokskriving er en del av jentekulturen (Jónsdóttir, 2001). Jentenes logg viste seg også å være et egnet materiale å bygge intervjuguide på. Ut fra foreløpige analyser av loggbøkene og erfaringer fra fellessamlingen bestemte jeg meg for å kalle jentene inn til fellesintervjuer, to og to gruppert på tvers av klasser. Hver av jentene fikk konkrete oppfølgingsspørsmål fra det de hadde skrevet i loggbøkene, men hovedtemaet var jentenes forhold til naturfag både retrospektivt og prospektivt og deres syn på og tiltro til naturvitenvitenskap. Intervjuene ble transkribert på samme måte som i det første intervjuet.

\section{Analysearbeid}

Analysearbeidet har gått parallelt med datainnsamlingen. I starten ble hver jente behandlet som en case. I den første fasen ble materialet kodet i brede tematiske emner, deretter analysert ut fra innholdet i hvert tema. Et tilbakevendende punkt i flere tema er jentenes omtale av kroppen. Dette funnet førte i neste omgang til at kroppen ble gjort til en egen kode. Ved innholdsanalyse av denne koden dukket det opp spørsmål som jeg ikke fant svar på i mitt datamateriale. Spørsmålene ble fulgt opp ved å sende tekstmeldinger med konkrete spørsmål. Et eksempel på et spørsmål som alle jentene fikk via sms er: Hvorfor trener $d u$ ?

Analyser av observasjoner dannet grunnlag for intervjuer, og analyser av fellessamlingen og loggbøker ble fulgt opp i fellesintervjuer og i konkrete spørsmål til jentene. Hele tiden har metoden bygd på en tanke om at datainnsamling og analyse skal være vevd sammen (Corbin, 1990). Min undersøkelse har en eksplorerende karakter. Målet har vært å utvikle hypoteser om relasjoner i mitt materiale. Men allerede i utformingen av prosjektet har min kjennskap til tidligere forskning og relevant teori vært til inspirasjon. Ettersom analysene begynte å ta form, vokste det gradvis frem et mønster som har mange likhetspunkter med Becks teori om risikosamfunnet (Beck, 1997; Beck, Bonss, \& Lau, 2003; Beck, 1995). Dette sammenfallet gjorde at jeg foretok en ny inspeksjon av dataene, denne gangen i et samspill mellom dataene og inspirasjon hovedsakelig fra Becks teori, men med et supplement fra andre sentrale teoretikere innen det samme teorifeltet.

\section{TEORETISK TILNARMING}

\section{Kroppen som en del av identitetsarbeidet i det refleksive moderne}

I den sosiologiske tradisjonen kan identitet oppfattes langs to grunnlinjer, for det første den individuelle identiteten som peker mot hvem jeg er, hvem jeg vil være, og hvem jeg har blitt, og for det andre den kollektive identiteten som viser til tilhørighet til en gruppe som en opplever som lik seg selv, eller som en gjerne vil likne (Frønes, 2004). I psykologien har identitetsbegrepet tradisjonelt betegnet individets personlighetskjerne eller essens (Drotner, 1993). I nyere teori knyttet til modernitetsforståelse vektlegges identitetens skiftende og midlertidige karakter i det refleksive moderne. Identitet blir langt på vei beskrevet og forstått som et uferdig prosjekt som subjektet selv må konstruere og omdanne i møtet med samfunnets mangfoldige kontekster og endringsprosesser (Giddens, 1991; Guneriussen, 1999). Mine analyser bygger på en slik forståelse av identitet. I det refleksive moderne blir også kroppen en viktig del av dette prosjektet. Kroppen betraktes ikke lenger utelukkende som natur eller skjebne. Den engelske sosiologen Shilling foreslår at vi må anerkjenne at kroppen er ufullstendig fra fødselen av, derfor er alle kropper til en viss grad sosialt 
konstruerte (Flemmen, 1999; Shilling, 1994). Vi navngir kroppen med sosiale kategorier, og vi kontrollerer den ved blant annet hjelp av dietter og besøk i helsestudio. Familien, barnehager og skoler bidrar også til å forme og innprente kroppen.

Giddens (1996) påpeker at vårt syn på kroppen har endret seg fra noe som betraktes som "gitt", til et fenomen preget av valg og muligheter. Han hevder i denne sammenhengen at

Det, der kunne ligne en markant udvikling i retning af en narcissistisk dyrkelse af det kropslige udtryk, er i virkeligheden et udtryk for noget dybereliggende, som aktivt "konstruerer" og kontrollerer kroppen (Giddens, 1996, s 17)

I en studie, som tar for seg tre generasjoner norske kvinner, blir det hevdet at for den yngste generasjonen (dagens jenter) blir kroppen i mye større grad en del av deres personlighet som kan og bør forbedres (Nielsen, 2004). Kroppen blir et prosjekt der det å være sunn, frisk, vakker og ven, blir et personlig ansvar. For å utdype dette teoretisk vil jeg gå til Becks' begrep om risikosamfunnet.

\section{Risikosamfunnet}

Beck introduserte begrepet risikosamfunnet i sin bok Risikogesellschaft, som kom ut i 1986. Her hevdet han at det moderne samfunn i tillegg til å produsere produkter, varer og rikdom også produserer risiko. Beck har vært opptatt av å kartlegge det moderne. I sine analyser skiller han mellom den første, enkle moderniteten og den andre, refleksive moderniteten. Beck snakker om modernisering av det moderne samfunnet (Beck et al., 2003). Refleksiviteten i det refleksiv moderne viser ikke til det vi vanligvis forbinder med begrepet refleksive innen samfunnsforskningen. Slik Beck bruker begrepet refleksiv, betyr det noe mer enn bare å overveie eller tenke etter. Hos Beck handler det ikke bare om bevissthet og viten, men også om den ureflekterte, mekaniske, autonome og utilsiktede forandring av industrisamfunnets grunnlag (Nielsen, 1997).

Risikosamfunnet refererer ikke til at vi har blitt omringet av flere farer, men til at vi ikke lenger kan kontrollere følgene av våre sivilisatoriske beslutninger. Vi lever ikke lenger i den tro at vi er i stand til å kontrollere farene. Risikosamfunnets tema er ikke risikoene, men det å kontrollere dem (Beck et al., 2003, 2004). Det dreier seg altså ikke om en ytre risiko, men om en indre risiko, sier Beck. I alle samfunn har en til alle tider opplevd farer. Disse farene var tidligere forårsaket av eksterne faktorer (for eksempel guder, demoner eller av naturen).

Det historisk nye ved de risikoene en opplever i risikosamfunnet, er at de er konstituert vitenskapelig og samfunnsmessig. Dette gjør seg gjeldende i tredobbel forstand, mener Beck. Vitenskapen blir på en og samme tid en medvirkende årsak til, et redskap for å definere, samt et middel for å avhjelpe risiko. Derved skaper en nye markeder for vitenskapeliggjøring (Beck, 1997). Samtidig med at vitenskapen får en slik fremtredende plass, lever vi i uvisse. Giddens (1994) konstaterer at vi lever i en verden som er etablert gjennom refleksivt anvendt viten. Vi kan aldri være sikre på at et gitt element av denne viten ikke før eller siden revideres. Den gamle forståelsen av ordet å vite betyr ikke lenger det samme som å voere sikker. Giddens siterer i denne sammenheng Karl Popper, som hevder at: "al videnskab er bygget på flyvesand".

\section{Mellom frihet og forpliktelse i det refleksive moderne}

Den refleksive moderniteten handler imidlertid ikke bare om risiko. Begrepet risiko forutsetter beslutning og valg (Beck, 1997). Kontrasten mellom refleksjon og refleksivitet i Becks forstand blir åpenbar når han beskriver det moderne mennesket i det refleksive samfunnet som "I am I". Dette gjør han ved å trekke frem kontrasten til Descartes' berømte postulat: Jeg tenker, altså er jeg, som viser til refleksjon, mens "I am I" viser til refleksivitet. Beck argumenterer ofte ved hjelp av motpolene refleksjon og refleks. Reflekser kommer umiddelbart, og de er svevende. Ved å bruke reflekser vil Beck få frem at vi må handle og ta beslutninger raskt. Beck fremhever at flere og flere av våre livsarenaer frikobles fra de rammene tradisjonen gir. Dette fører til at vi må ta flere valg, avgjørelser og standpunkt i forhold til både private og offentlige aspekter ved våre liv, aspekter 
som før ble styrt av tradisjon og normer som ble tatt for gitt. Denne utviklingen kaller Beck individualisering. Individualisering skjer i en dialektisk prosess mellom fristilling (disintegration) og nyskaping (reinventation). I motsetning til poststrukturalistiske teoretikere mener Beck at både subjektet og kunnskapen fortsatt eksisterer. I en kommentar til Becks bruk av termen refleksivitet hevder Scott Lash (2003):

The subject is still with us and so is knowledge. Only knowledge itself is of uncertainty. What happens now is not non-knowledge or anti-reason. Indeed, in reflexive modernity we are better educated, more knowledgeable than ever. Instead, the type of knowledge at stakes changes. It is itself precarious as distinct from certain, and what that knowledge is about is also uncertain - probabilistic, at best; more likely 'possibilistic' (s52)

Med referanse til Beck drøfter Giddens hvordan samfunnsskapte strukturer har ført til at vi lever i en slags permanent risikotilstand (Giddens ,1994, 1996). Et hovedanliggende for Giddens har vært å belyse hvordan motpoler som risiko og tillit, farer og muligheter preger de fleste sider ved livet i det senmoderne. Vi er henvist til å stole på ekspertene ${ }^{5}$, mener Giddens (Giddens, 1994, 1996). Som et resultat av avsløringer av ekspertenes feiltakelser reflekterer vi samtidig over i hvilken grad vi skal ha tillit til de systemer vi er avhengige av. Vi lever og eksisterer altså i en verden med en kontinuerlig risiko for at ting og hendelser ikke får den utgang vi forventer.

Individualiseringen har både en progressiv og en regressiv side (Beck, 1997). De valgmuligheter individualiseringen åpner opp for, kan skape gevinster her og nå. De samme gevinstene kan vise seg å være morgendagens begrensninger (Elliot, 2002). Beck og Beck-Gernsheim (1995) illustrerer dette ved hjelp av teknisk innovasjon i medisinsk forskning. Utviklingen i diagnostikk og gentesting gir foreldre nye muligheter til helsekontroll av det ufødte barnet. Disse medisinske nyvinningene kan imidlertid oppleves som en forpliktelse foreldrene har til å bruke denne teknologien for å sikre en frisk start for sitt avkom. Her får individualiseringen et paradoksalt preg av tvang. På den ene siden fører individualiseringen til at vi får et nært og aktivt forhold til vitenskap og teknologi. På den andre siden blir vi stilt overfor problemstillinger med tidligere ukjente moralske og etiske implikasjoner (Elliot, 2002). Tradisjonelt har naturvitenskapen blitt betraktet som både sikker og verdifri (Ravetz, 1999). Den økte kompleksiteten i de problemstillinger vitenskapssamfunnet arbeider med, har ført til økt faglig uenighet og større vitenskapelig usikkerhet (Kaiser, 2000; Ravetz 1999). Denne usikkerheten er ikke bare forbeholdt forskerkollektivet og beslutningstakerne. Den gir seg også utslag blant det allmenne publikum.

\section{DYPDYKK I EMPIRIEN}

Jeg har tidligere vist til undersøkelser som viser markante kjønnsforskjeller i rekruttering til realfag (NIFU 2002). Jentene i min undersøkelse føyer seg pent inn i denne statistikken. Dette viser seg også når jentene snakker om temaer i naturfag som de liker godt. Således legger jentene vekt på å understreke at deres interesse for temaet kroppen ikke bunner i tanker om yrker innenfor helsesektoren. Denne artikkelen tar ikke opp diskusjonen om hvorfor jentene ikke er interesserte i dette.

Innledningsvis hevdet jeg at de ni jentenes interesse for emnet "kroppen min" kan forståes med utgangspunkt i deres opplevelse av helserisiko og behov for å kontrollere egen kropp. Dette knytter jeg opp mot en forståelse av kroppen som en viktig del av identitetsarbeidet i det refleksive moderne. Jeg bruker jentenes holdninger til naturvitenskapen som et omdreiningspunkt for å forstå deres interesse for kroppen. I denne delen av artikkelen skal jeg gå disse påstandene nærmere etter i sømmene, blant annet på bakgrunn av de refererte teoretiske perspektivene.

\footnotetext{
${ }^{5}$ Giddens skiller mellom på den ene siden ansikt - til ansikt forpliktelser som kjennetegnes av tillitsrelasjoner. Disse relasjonene understøttes av sosiale forbindelser. På den andre siden ansiktsløse forpliktelser, som dreier seg om tro på symbolske tegn eller ekspertsystemer. Dette betegner Giddens med fellestermen abstrakte systemer
} 


\section{Mellom tillit og tvil}

Jeg finner i mitt materiale en betydelig usikkerhet blant jentene når de skal vurdere kvaliteten og sannhetsgehalten i nyheter fra forskningsfronten: Det er liksom sånne perioder der det kommer opp at absolutt alt mulig er kreftfremkallende og så har de ikke noe sånn spesielle begrunnelser for at det er kreftfremkallende. Hvis de hadde hatt en begrunnelse, hadde jeg kanskje hørt litt på det, og hvis det hadde vaert flere som hadde kommet frem til det og ikke bare en forsker, liksom. Det er akkurat det samme når det gjelder de som har forska på ungdom og godteri. De går inn på en skole, virker det som. De går inn på en stor skole, $i$ en stor by. Så forsker de der, og så er det konklusjonen for alle ungdommer, det blir liksom...nei, sier Petra og sukker tungt.

Her viser Petra innsikt i at forskning er et komplekst fenomen. Hun stiller seg kritisk til forskningsfunnenes sannhetsverdier. Hun etterlyser begrunnelser, og hun stiller spørsmål ved hvilke grunnlag det er mulig å generalisere på. Samtidig gir hun et uttrykk for den frustrasjonen mange av de andre jentene tilkjennegir. Hvordan skal de vurdere holdbarheten i den informasjon de får? Petras betraktninger kan også ses i lys av Giddens' (1996) iakttakelser av sameksistensen mellom motpolene tillit og skepsis i vår tid. Han hevder i denne sammenheng at holdningene til lekfolk bærer preg av den samme ambivalente innstillingen til vitenskap, teknologi og andre esoteriske former for ekspertise som filosofer og sosialforskere gir uttrykk for i sine verker. En slik ambivalens til vitenskap og forskning finner jeg hos jentene. Metaforen flyvesand (jfr. Popper/Giddens, som jeg tidligere har referert til) blir et treffende bilde som kan forklare den frustrasjon jentene opplever i møtet med omskiftelige råd fra eksperter. De slites mellom tillit og tvil til vitenskap og forskning. Deres frustrasjon handler også om at kunnskapsmengden øker.

\section{Når viten oppleves som en belastning}

I materialet finner jeg at jentene ser på naturvitenskap som en vitenskap i utvikling. Dette blir spesielt tydelig når jeg spør dem om de tror at naturfagundervisningen har endret seg fra den gang deres bestemødre var unge. Dette svarer jentene på ved å vise til kunnskapsutvikling i naturvitenskapen. Samtidig signaliserer flere av jentene at den økte kunnskapen kan føre til at det kan være vanskelig å orientere seg. Dette kan også oppleves som en kilde til frustrasjon. I et fellesintervju med Lea og Maja sier Lea: De funnet ut så masse mer. Jeg har på følelsen at de ikke gikk så voldsomt detaljert inn i ting som vi giør, sier Lea. I hvert fall ikke jenter, tilføyer Maja. Det er påfallende at de eksemplene jentene bruker for å beskrive denne kunnskapsutviklingen, er preget av problemstillinger som handler om risiko. Eksemplene handler blant annet om sykdommer og drivhuseffekt. Jentenes refleksjoner kan ses i lys av teorien om risikosamfunnet, der kilden til farer ikke lenger er "ikke-viten", men "viten", i følge Beck. Det er ikke den natur som er uberørt av mennesker som truer, men det system av føringer og beslutninger som ble etablert av industriepoken, mener han (Nielsen, 1997). Samfunnet har nådd et nytt utviklingsstadium, men sleper samtidig på noe av arven fra tidligere industrialiserte epoker. Beck et al. (2003) argumenterer for at denne arven er en tung bør som fremtrer som faretruende på flere plan. Det som tidligere symboliserte fremskritt, forbindes i dag i stedet med sløsing, ødeleggelse eller direkte utryddelse av våre naturressurser. Beck presiserer at:

Modernity has not vanished, but it is becoming increasingly problematic. While crises, transformation and radical social change have always been part of modernity, the transition to a reflexive second modernity not only changes social structures but revolutionizes the very coordinates, categories and conceptions of change itself (Beck et al., 2003, s 2).

Det er mulig å forstå jentenes utsagn slik at det er i denne "transitthallen" mellom den enkle og den refleksive moderniteten jentene skal orientere seg og vurdere kvaliteten på den informasjon de utsettes for. Dette kan illustreres med Leas refleksjoner: Jeg er en sånn person som tror alt jeg 
leser [latter], men nå $i$ det siste så har jeg funnet ut at det er ikke alt som stemmer liksom og ... du må ikke tro alt du leser. Du må ikke tro på det sier alle vennene mine. For at jeg skal tro på ting må høres litt sånn logisk ut. Ja, det er vel det eneste du må, liksom tenke selv: Høres dette noen lunde greit ut, liksom?

Hvordan denne ambivalensen mellom tillit og tvil kan komme til syne i forhold til de tre temaene trening, kosthold og sex, som jentene er spesielt opptatt av i forbindelse med temaet kroppen, vil jeg illustrere nedenfor.

\section{Trening: Når kroppen skal trenes, og jentene selv må være byggherrer}

Jeg trener for å holde meg i form, og fordi det er kjekt, sier Maja. Hennes svar er typisk for jentene, som alle trener jevnlig. Svaret er i samsvar med undersøkelser som viser at hovudmotivet for trening i denne aldersgruppa er det samme Breivik (2003). Vedlikehold av kroppen anser jentene som sitt ansvar. Det er påfallende at flere av jentene nevner at naturfaglig kunnskap om kroppen er nyttig i forhold til trening. Hos disse jentene er ikke kroppen forbeholdt gymsalen. Refleksjonene til to av jentene, Benedicte, som går på allmennfaglig linje og Sara, som går på idrettsfaglig linje, illustrerer dette godt.

Første semester på videregående skole skriver Sara om naturfagtimene i loggboka: I dag hadde vi om oppbygging av kroppen og energi kroppen trenger. Det meste av energien fär vi igjennom karbohydrat og fett. Vi hadde litt om hva kroppen trenger til hva. Hadde også litt om hva skjer hvor? For eksempel i munnen er det spytt. Vann som gjør at maten sklir letter ned, hvor mye vi skal tygge maten, og løser den opp ved hjelp av magesyre osv. Jeg syns det var spennende å loere om dette $i$ dag, mye kjekkere enn vanlig kjemi som vi hadde før dette kapitlet, det er veldig tregt syns jeg. Dette er nyttig å loere om fordi det handler om kroppen vår og hvordan den fungerer. Neste år skal vi $i$ idrettsklassen gå mer innpå kroppen, derfor er det ekstra interessant nå. Sara ønsker i likhet med de andre jentene å bruke naturfaglig kunnskap som en referanseramme i forhold til trening. Dette finner jeg også i et fellesintervju med de to jentene, der Benedicte blant annet sier at hun kunne tenkt seg å lære mer om muskler og beinbygging. Ja, det har jeg lyst til å loere om. Hvordan kroppen fungerer og sånn. Det synes jeg er interessant.

Inntrykket blir styrket da jeg underveis i analysearbeidet sender tekstmeldinger til jentene der jeg spør: Hvorfor trener $d u$ ? Samtlige av jentene trekker igjen frem sunnhet og helse.

Men samtidig som jentene snakker om trening og kropp på en nøktern måte, reflekterer de også over kroppsfiksering, som de mener spesielt jenter utsettes for. Det presset som jentene opplever, mener de er en av grunnene til at emnet "kroppen min" er litt jentete, som Benedicte uttrykker det. Igjen er det risiko som står i fokus når Sara føyer til det er jentene som slanker seg, og det er de som får sykdommer.

Hvis det er riktig at kroppen blir en viktig del av jentenes identitetsprosjekt, et prosjekt som de opplever å ha hovedansvar for, innebærer det at de må foreta en rekke valg og beslutninger. Dette er i tråd med det Shilling mener når han snakker om at kroppen til en viss grad er sosialt konstruert og noe den enkelte selv må kontrollere (Shilling, 2003). Jentenes higen etter å lære om muskler, beinbygging og det optimale kosthold, for å få størst mulig utbytte av sin egen fysiske fostring, kan også forstås i lys av kjennetegn ved den refleksive moderniteten. Således fremholder Giddens at det moderne livet kjennetegnes av at vi vurderer kontinuerlig våre handlinger $\mathrm{i}$ lys av ny kunnskap og informasjon. En stor del av den kunnskap som produseres i vitenskapelige institusjoner, tilbakeføres til lekfolk og fungerer i visse tilfeller som grunnlag for kritiske vurderinger av ulike sosiale fenomen (Giddens, 1994). Giddens sikter her først og fremst til sosiologiske og psykologiske fenomen, men spørsmålet er om dette ikke også gjelder naturvitenskapelig kunnskap. Jentene anvender ikke naturfaglige begreper direkte, men naturfaglig kunnskap blir mer en 
generell referanseramme. Denne kunnskapen blir for jentene et potensielt redskap for å definere de valgmuligheter de står overfor. På samme tid utsettes de for en flom av informasjon om kroppen i media, gjennom reklame og i den generelle samfunnsdebatten. For å sette dette i relieff har jeg i intervjuene blant annet brukt reklame for å konkretisere spørsmålet om hvordan de forholder seg til denne informasjonen.

\section{Hvordan takler jentene ikke-viten i møte med reklame som lover et miljøvennlig leppe- løft?}

Reklamen ${ }^{6}$ som jeg brukte, hadde overskriften et miljøvennlig leppeløft. Her får du et løfte om et lite, men sexy løft for leppene. Thea ler: Vennlig mot huden, eller noe sånt. Nei, jeg vet ikke, sier hun. Alle skal voere det, liksom. Men det er ikke alle som er det, egentlig, føyer hun til og sukker. Theas skepsis til denne reklamen illustrer godt hvordan også de andre jentene møter denne typen påstander. Deres reaksjoner kjennetegnes av tvil og oppgitthet: Det er dette som er så vanskelig, utbryter Lea, hva skal en tro på. Anna takler derimot sin oppgitthet med ironi og en påfallende bevissthet om reklamespråkets virkemidler. Når jeg spør henne: Hva tenker du når du leser dette? sier Anna reklame, og ler. Ja, her skal man selge et produkt, da hjelper det å si at man får et lite men sexy løft i leppene. Tror du det fungerer? spør jeg. Helt sikkert, svarer hun og geiper voldsomt. Og hun fortsetter med fordreid stemme: Ja, det tror jeg nok når det att på til er miljøvennlig så hvorfor ikke? Ja, og de som er opptatt av at ikke er testet på dyr og sånn, det er mange som er det. Så ja, det tror jeg. Nå skal jo alle voere så økologiske og sånne ting. Det tror jeg også er en trend at miljøvennlig leppestift selger bedre enn vanlig leppestift. I sin ironisering viser Anna innsikt i reklameverdens virkemidler, som i dette tilfellet har hentet formuleringer fra naturvitenskapelig forskning om økologi og miljøvern. Dette eksemplet illustrerer også hvordan jentene kan velge å takle sin "ikke- viten" med henholdsvis oppgitthet (Lea) og ironi (Anna).

Hvordan jentene takler sin "ikke- viten" i møtet med denne reklamen kan også forståes i lys av Becks teori om risikosamfunnet. Beck et al. (2003) påpeker at når vi betrakter de utilsiktede sideeffektene av den enkle moderniseringen som en mental konstruksjon, blir spørsmålet om hvem som kan eller skal definere risiko viktig.

...conflicts between the definitions of risk put forth by scientific experts and those of political actors lead to institutional legitimation deficits. Scientific reasoning can no longer solve such situations the way it once did, because technical standards of safety are now confronted by the conviction that some things are in principle uncertain (Beck et al., 2003, s 14).

Beck et al. snakker i denne sammenheng om at politiseringen av disse sideeffektene drives frem av beslutningstakere (opposed interests), profittmakere og berørte samfunnsgrupper, denne prosessen forløper relativt uavhengig av den aktuelle risiko. Eksemplet med reklamen for det miljøvennlige leppeløftet tjener også som et eksempel på hvordan vitenskapen brukes på stadige flere av våre livsområder (Beck, 1997). Dette er en realitet som jentene må forholde seg til i forhold til sitt identitetsarbeid der kroppen utgjør en viktig bestanddel. Jentenes refleksjoner rundt denne reklamen er et eksempel på hvordan jentene takler sin ikke-viten.

\section{Kosthold: Jentene føler at de ikke kan vite om slankebrød virker}

Hvordan jentene takler og møter sin ikke-viten blir enda tydeligere når jeg bringer på banen en aktuell samfunnsdebatt (våren 2003): Kan diettene voere helseskadelige? Alle jentene er godt

\footnotetext{
${ }^{6}$ Jeg har hentet reklamen fra ungdomsbladet Mag. Samtlige av mine informanter kjente bladet, hadde lest det og noen hadde abonnert på det. I følge opplysninger fra den lokale Narvesen butikken, er Mag det mest solgte "jentebladet” i Bygdeby. På sin hjemmeside presenterer bladet seg med følgende slogan: Mag er bladet for deg som vil holde deg oppdatert innen trender, film, moter m.m. Mye kul lesning!
} 
kjente med debatten rundt Fedon Lindberg ${ }^{7}$ : Han har jeg hørt om ja, han har tatt livet av poteten $i$ familien vår omtrent, sier Anna og ler. Plutselig tok alle bare en potet, istedenfor to, så det var dobbelt så mange poteter. Man blir jo påvirket, tror jeg eller sånn.. prøve det ut. Men altså, brød har alltid voert $i$ norsk tradisjon, for eksempel og folk, altså vi, blir jo bare feitere og feitere nå så jeg tror ... Det eneste jeg tror nytter er at folk spiser sundt, regelmessig og trener og glemme alle sånne slankekurer. Altså spis en brødskive med gulost og ett glass melk til frokost og så spiser du fire timer senere et sundt måltid og så jeg tror ikke det har så mye med det å gjøre egentlig.

Petra viser også til norsk mattradisjon når hun argumenter mot Fedon Lindbergs slankekur: Egentlig så vet jeg ikke helt, men det virker så tåpelig med alt det der nye greiene med slankebrød eller hva det er for noe. For det er liksom. det vi har spist før, det har nå holdt helt fint, derfor synes jeg hvorfor skal vi begynne å lage masse nye ting. Jeg tror ikke det er så veldig godt heller, men det vet jeg egentlig ikke, for jeg har ikke smakt det, men...

Lea virker derimot oppgitt: Nei jeg vet ikke hvem du kan tro på, det er det som er så vanskelig. Benedicte synes dette høres ganske teit ut. Det der tror jeg ikke litt på en gang. Når jeg spør hvorfor ikke?, ler hun og sier: Sier ja til fett og proteiner og fy til poteter og brød, nei og så ler hun igjen. Her ser vi hvordan Benedicte implisitt bruker naturfaglig kunnskap i sin argumentasjon. De andre jentene er i likhet med Benedicte ikke villige til å diskutere saken noe videre. Når jentene blir usikre på hva de skal tro og stole på, prøver de å løse dilemmaet med å vise til norske mattradisjoner og etablert forskning. Samtidig signaliserer jentene at man kan jo ikke vite, kanskje strekker ikke etablert kunnskap helt til? Vi blir jo bare feitere og feitere, sier Anna. Dette er interessant sett i lys av Beck og Giddens sine teorier om den tiden vi lever i. Begge drøfter de hvordan vi lever i grenselandet mellom den enkle moderniteten og den refleksive moderniteten. Giddens (1994) drøfter forholdet mellom tradisjon og viten. Han påpeker at hverdagsrutiner kan begrunnes ved hjelp av tradisjoner bare hvis disse tradisjonene er i samsvar med gjeldende vitenskap.

Når jentene her henviser til norske mattradisjoner, henviser de til en tradisjon som er etablert viten innenfor ernæringsfysiologi. Jentenes reaksjon kan også ses i lys av ekspertenes svekkede rolle i en postnormal vitenskapelig kontekst. Spørsmålet om hvem som skal og kan uttale seg om og definere risiko, står åpent, og det skaper usikkerhet. Ovenfor har vi sett at i dette tilfellet velger jentene å søke "støtte" i "gårsdagens" vitenskap, som har fått status som god norsk mattradisjon.

\section{Sex: Når jentene er midt oppe i det, føler de at det er med risiko i sikte}

Når jeg spør Lea hvilke tema hun hadde likt best i tiende klasse, svarer hun: Seksualitet og samliv var ganske moro, for vi er liksom midt oppe $i$ det nå, og da er det ganske interessant. Leas svar gir et godt bilde av jentenes holdninger. Seksualitet er et tema som de ikke uventet er opptatt av. Deres interesse blir enda tydeligere når de møter temaet i filmens verden. Den første høsten på videregående skole har samtlige av de ni jentene vært på kino og sett filmen Bare Bea. Den handler om en jente som i likhet med dem selv går første året på videregående skole. Hovedpersonen Bea er den eneste i venninnegjengen som ikke har debutert seksuelt. Hennes venninner, som er skråsikre på når, med hvem og hvordan man bør debutere, setter i gang en redningsaksjon for Bea. Mine informanter er svært opptatt av filmen, men på noen områder mener de at filmen er urealistisk. Jeg kjente meg igjen, men ikke så ekstremt som det der, sier Anna. Det er ikke sånn at man snakker om at de som ikke har gjort det, bare må gjøre det. Det der ville jeg kalle sex press. Direkte press fra venner og sånn, gjør vi bare ikke i virkeligheten. Men jeg satt og lo godt for jeg syntes det var mange situasjoner der som jeg kunne kjenne meg igjen $i$. Lone og Thea er i likhet med Anna opptatt av at filmen ikke er en sann beskrivelse fra virkeligheten. Filmen var bra, men

${ }^{7}$ en norsk indremedisiner og forfatter. I 2001 ga han ut boken Naturlig slank med kost i balanse. Linberg forfekter det han karakteriserer som: et kosthold tilpasset kroppens genetiske forutsetninger. Han hevder at kalorimengden har mindre betydning enn fordelingen mellom karbohydrater, protein og fett. Dette har avstedkommet en heftig debatt i ulike media omkring hva kan og skal regnes som godt norsk kosthold. 
den ble litt urealistisk synes jeg, sier Lone. Det er jo ikke sånn det egentlig er. Thea er helt enig og føyer til: Nei, sånn som da hun Bea ble invitert på fest, du trenger ikke å ha sex fordi du blir invitert på fest, liksom.

Jentenes refleksjoner rundt denne filmen, sett i sammenheng med de holdninger de ellers gir uttrykk for, forsterker ønsket om å fremstille seg som selvstendige, slik jeg ser det. I andre sammenhenger har jentene uttalt seg om blant annet valg av studieretning på videregående skole, organiserte fritidsaktiviteter, klesstil og musikksmak. På alle disse områdene markerer jentene sterkt at de må finne sin egen vei uavhengig av hva foreldre, venner og omgivelsene for øvrig måtte foretrekke. Jeg er meg, og jeg må velge det jeg mener er riktig og det jeg synes er viktig, er en oppfatning som jeg ofte finner i materialet. Dette betyr ikke at jentene er uberørt av sine omgivelser. Ved flere anledninger uttrykker de blant annet at venner er det viktigste som finnes. Mor, far, ja til og med besteforeldre blir ofte nevnt som referanse til både det ene og det andre. Men ingen av disse referansene kan brukes som modeller for jentenes egne valg. Dette kan ses i lys av begrepet relasjonell individualisme (Nielsen, 2004). Begrepet viser til hvordan jenter vektlegger relasjoner til andre når de reflekterer over seg selv som individer.

Jentene gir uttrykk for at de i møtet med sex som tema i naturfagundervisningen, er spesielt interesserte i å tilegne seg naturfaglig kunnskap som de kan bruke for å minske farer forbundet med sex. De mener at slike problemstillinger burde hatt større omfang i naturfag. Flere av jentene nevner i denne sammenheng helsesøster på skolen. Til tross for at jentene opplever at helsesøster har en åpen-dør-politkk, kan hun allikevel ikke erstatte den kunnskapen de mener naturfagundervisningen burde bidra med. De opplever at helsesøster og naturfag har ulike funksjoner i forhold til deres behov for kunnskap om sex. Helsesøster kan de gå til med akutte problemstillinger knyttet til deres livssituasjon her og nå. I naturfag etterlyser jentene mer problematisering av risiko forbundet med for eksempel bruk av prevensjon og utvikling av kjønnssykdommer. Jeg synes vi hadde så alt for lite om det, vi hadde bare en uke med det, liksom, sier Sara.

Jentene utviser stor tillit til at naturvitenskapen kan være et middel til å avhjelpe denne typen risiko som de er opptatt av. Annas uttalelse fanger opp det mange av jentene er inne på i denne sammenheng. Hvordan de har fremstilt en pille som giør at du ikke blir gravid, det er interessant. Det er sånne ting jeg interesserer meg for $i$ naturfag. Det handler om meg liksom. Det er til meg, vitenskap til meg, sier Anna. Samtidig reflekterer flere av jentene også over hvordan de lever med sin "ikke-viten". De stiller spørsmål ved hvordan de skal klare å leve med at de ikke kan finne sikre svar på sine spørsmål. Thea sukker og sier: Vi hadde nesten ikke noe om det. Det er litt dårlig, synes jeg. Vi vet jo masse, men vi vet ikke alt, mindre enn vi tror. Ja, det er masse du ikke vet. Hva kunne du tenkt deg å vite mer om? Spør jeg. Hvordan du kan bli smittet av kjønnssykdommer, og hvordan du kan passe deg mot det. Jeg vet jo en del,... eller alle vet, men det er ting vi faktisk ikke vet. Vi bare tror vi vet. Mange av jentene gir uttrykk for at naturfag slik de møter faget på videregående skole, ikke møter det behovet de har. Faget fremstår som faktapreget og vanskelig, og da må de søke andre steder for å få svar på sine spørsmål. Sara og Benedicte bemerker i denne sammenheng at de loerer jo masse av å lese blad. Du gjør det, det er jo ganske interessant også, sier Sara. Og Benedicte er helt enig: Ja det er det. Det er masse å lese, sier hun. Det ligger på en måte ikke i loereplanen, føler jeg. Jeg vet ikke. For eksempel det vi har nå. Det er mer muskler og hva som skjer i både mannekropp og kvinnekropp, legger Sara til.

\section{MED KROPPEN I TRANSITTHALLEN? - OPPSUMMERENDE KOMMENTARER}

Hvordan kan vi forstå jentenes interesse for temaet kroppen i naturfag? Dette spørsmålet var utgangspunktet for denne artikkelen. Min påstand er at denne interessen kan forståes med utgangspunkt i deres opplevelse av helserisiko og behov for kontroll av egen kropp. Jeg har brukte Ulrich Becks teori om risikosamfunnet for å belyse sammenhenger i jentenes tanker rundt dette. 
Gjennom å betrakte kroppen som en del av identitetsarbeid i det refleksive moderne åpnes det opp for alternative måter å forstå jentenes interesse for kroppen. Moderne refleksivitet er nært knyttet til valg. Det får konsekvenser for jentenes identitetsarbeid. Daglig stilles de overfor et mangfold av valgmuligheter. Hvordan dette kommer til utrykk hos jentene, i forhold til kosthold, trening og helserisikoer forbundet med sex, har jeg forsøkt å vise gjennom mine dypdykk i empirien. Tradisjoner har mistet sin kraft, de er ikke lenger nedarvet og kan derfor ikke være en veiviser for jentene når de skal velge. Beck (1997) kaller denne utviklingen individualisering. Stadig flere av våre livsområder vitenskapliggjøres. Den vitenskapen som jentene føler seg avhengige av, opplever de som flyktig og usikker. På samme tid ser vi at jentene er avhengige av ekspertsystemer som de verken kan styre eller forstå. Dette har vært min innfallsvinkel i analysen når jeg har brukt jentenes syn på vitenskap som et omdreiningspunkt for å forstå deres interesse for temaet kroppen i naturfagundervisningen. Jeg har brukt metaforen transitthall mellom det moderne og det refleksive moderne for å beskrive den konteksten jentene er i når de skal forholde seg til vitenskapen. Jentene utsettes for en flom av informasjon om kroppen som er smidd over samme lest, og der budskapet oppleves som klart: Kroppen er deres eget ansvar. Vi har sett hvordan jentene ønsker å ta dette ansvaret. Offentlige helsekampanjer, reklame, ukeblader og tv-programmer som tar for seg det sunne liv, tar i bruk en vitenskapelig sjargong som virkemiddel. I det refleksive moderne betraktes sunn livsstil som den enkeltes ansvar. Det er i denne jungelen jentene skal orientere seg og treffe valg og beslutninger som de opplever som en viktig del av sitt identitetsarbeid. De ni jentene responderer på denne tenkningen med et ønske om at skolens naturfag skal gi dem holdepunkter som de kan bruke for å orientere seg i denne jungelen og avhjelpe den typen risiko de er opptatt av. Slik jentene opplever naturfag, fremstår det som faktapreget og arbeidskrevende. Når jentene etterlyser mer tid brukt til temaet kroppen er det først og fremst de komplekse problemstillingene, de som Funtowicz og Ravetz (1993) betegner som postnormal vitenskap, de ønsker mer av, men som de ikke synes skolen gir dem nok naturvitenskapelig kunnskap om.

\section{REFERANSELISTE}

Beck, U. (1997). Risiko og frihet. (A. Eriksen, overs.). Bergen-Sandviken: Fagbokforlaget. (Original publisert: Forord og første del 1986, Andre del 1995, Tredje del 1996, Etterord 1997)

Beck, U., Bonss, W., \& Lau, C. (2003).The Theory of Reflexive Modernization. Theory, Culture \& Society, 20(2), 1-33

Beck, U., \& Beck-Gernstein, E. (1995). The Normal Chaos of Love. (M. Ritter og J. Wiebel overs.) Cambridge: Polity. (Orginal publisert 1990)

Breivik, G. (2003). Moderniseringsprosesser i idretten. Aktivitet og medlemskap i vekst og fall, Forelesning på Forskerseminaret Idrett, inklusjon og modernisering. Lysebu.

Brickhouse, N., Lowery, P., \& Schultz, K. (2000). What kind of a girl does science? Journal of research in science teaching, 37(5), 441-458.

Børtnes, J., Kraft, S.E, \& Mikaelsson, L. (Red.). (2004). Kampen om kroppen. Kulturanalytisk blikk på kropp, helse, kjønn og seksualitet. Kristiansand: Høyskoleforlaget.

Corbin, A. L. S., \& Corbin, J. (1990). Basics of qualitative research: grounded theory procedures and Techniques. California: Sage.

Drotner, K. (1993). Køn og kulturell ambivalens (s 170- 193). I K. Drotner, \& M. Rudberg (Red.), Dobbelblikk på det moderne. Unge kvinners hverdagsliv og kultur i Norden. Oslo: Universitetsforlaget.

Elliot, A. (2002). Beck's Sociology of Risk: A Critical Assessment. Sociology, 36, 293-315.

Fenstermaker, S., \& West, C. (2000). Doing Gender, Doing Difference - Inequality, Power, and Institutional Change. New York - London: Routledge

Flemmen, A. B. (1999). Kroppsliggjort subjektivitet (s119-135). I A.T., Lotherington, \& T. Markussen (Red.), Kritisk kunnskapspraksis. Bidrag til feministisk vitenskapsteori. Oslo: Spartacus.

Frønes, I. (2004). Identitet, tegn og kultur - Om identitet i sosiologisk teoridannelse. Sosiolog $i$ dag, 3, 27-53. 
Giddens, A. (1991). Modernity and self-identity: self and society in the late modern age. Cambridge: Polity Press.

Giddens, A. (1994). Modernitetens konsekvenser. København: Hans Reitzels forlag.

Giddens, A. (1996). Modernitet og selvidentitet. selvet og samfundet under sen-moderniteten. København: Hans Reitzels forlag.

Guneriussen, W. (1999). Å forstå det moderne. Oslo: Tano Aschehoug.

Holsen, I. (2002). Depressed mood from adolescence to "emerging adulthood": course and longitudinal influences of the body image and parent-adolescent relationship. Bergen: Research Centre for Health Promotion, Faculty of Psychology, University of Bergen.

Jónsdóttir, G. (2001). SKOLEDAGBOKA. Samarbeid med to ungdomsskolejenter våren 1999 og tre elever fra videregående høsten 2001. (Ikke publisert notat).

Kaiser, M. (2000). Hva er vitenskap? Oslo: Universitetsforlaget.

Lash, S. (2003). Reflexivity as non-linearity. Theory, Culture \& Society, 20, 49-57.

Madriz, E. (2000). Focus Groups in Feminist Reaserch (s 835-869). In Denzin, N. K., \& Y. S. Lincoln, (Red.), Handbook of qualitative research. Thousand Oaks, California: Sage.

Nergård, T. (2003). Jenter liker ikke naturfag, i hvert fall ikke fysikk og kjemi (s 143-164). I D. Jorde, \& B. Bungum (Red.), Naturfagdidaktikk. Perspektiver, forskning, utvikling. Oslo: Gyldendal Akademisk.

Nielsen, H. B. (2004). Noisy girls. New subjectivities and old gender discourses. Young. Nordic Journal and Youth Research, 12 (1), 9-30.

Nielsen, T. H. (1997). Introduksjon. Å tenke seg ut av industrisamfunnet. I U. Beck, (1997). Risiko og frihet. (A. Eriksen, overs.). (s 5-13). Bergen-Sandviken: Fagbokforlaget. (Original publisert: Forord og første del 1986, Andre del 1995, Tredje del 1996, Etterord 1997.)

NIFU (2002). Rekruttering til studier i matematikk, naturvitenskap og teknologi i de nordiske landene. En oversikt over tiltak og de siste års utvikling. Oslo: NIFU og Nordisk Ministerråd.

Osborne, J., Simon, S., \& Collins, S. (2003). Attitudes towards science: a review of the literature and its implications. International Journal of Science Education. 25(9), 1049-1079.

Ravetz, J. R. (1999). What is Post-Normal Science? Futures, 3, 1647-653.

Roger, A., \& Duffield, J. (2000). Factors Underlying Persistent Genderd Option Choices in School Science and Technology in Scotland. Gender and Education, 12, 367 - 383.

Rudberg, M.(2000). Kroppen kommer hjem. Hvordan epistemofilen havnet på Ally McBeals do. Norsk Medietidsskrift, 1, 43-59.

Schreiner, C., \& Sjøberg, S. (2003). Optimist or pessimist? How young people relate to environmental challenges? Konferanse ESERA (European Science Research Association). Netherlands.

Schwandt, T. A. (2000). Three Epistemological Stances for Qualitative Inquiry: Interpretivism, Hermeneutics, and Social Constructionism (s 189-213). I N. K Denzin, \& Y.S. Lincoln, (Red.), Handbook of Qualitative Research (2nd ed.). Thousand Oaks, California: Sage Publications.

Shilling, C. (1994). The body and social theory. London: Sage.

Simon, S. (2000). Students' attitude towards learning science. I M. Monk, \& J. Osborne, (Red.), Good Practice in Science Teaching. What research has to say. (s 104-122). Bucingham, Philadelphia: Open University Press.

Sjøberg, S. (2001). Fagdebatikk - Fagdidaktisk innføring i sentrale skolefag. Oslo: Gyldendal Akademisk.

Sjøberg, S. (2002). Science for the children. Report from the Science and Scientist-project. Oslo: Universitetet i Oslo.

Sjøberg, S. (2004). Naturfag som allmenndannelse, en kritisk fagdidaktikk. (2.utg). Oslo: Gyldendal Akademisk.

Teppo, M., \& Rannikmäe, M. (2004). Relevant science education in the eyes of grade nine students, Konferanse IOSTE 11 (International Organization for Science and Technology Education). Poland.

Wadel, C. (1991). Feltarbeid i egen kultur, en innføring i kvalitativt orientert samfunnsforskning. Flekkefjord: SEEK. 